\title{
Laccase-mediated oxidations of propargylic alcohols. Application in the deracemization of 1-arylprop-2-yn-1-ols in combination with alcohol dehydrogenases
}

\author{
Sergio González-Granda, ${ }^{[a]}$ Daniel Méndez-Sánchez, ${ }^{[a, b]}$ Iván Lavandera*[a] and Vicente Gotor- \\ Fernández $z^{*[a]}$ \\ Dedicated to Professor Marko D. Mihovilovic on occasion of his $50^{\text {th }}$ birthday.
}

\begin{abstract}
The catalytic system composed by the laccase from Trametes versicolor and the oxy-radical TEMPO has been successfully applied in the sustainable oxidation of fourteen propargylic alcohols. The corresponding propargylic ketones were obtained in most cases in quantitative conversions ( $87->99 \%$ yield), demonstrating the efficiency of the chemoenzymatic methodology in comparison with traditional chemical oxidants, which usually lead to problems associated with the formation of by-products. Also, the stereoselective reduction of propargylic ketones was studied using alcohol dehydrogenases such as the one from Ralstonia species overexpressed in E. coli or the commercially available evo-1.1.200, allowing the access to both alcohol enantiomers mostly with complete conversions (97->99\% ee) and variable selectivities depending on the aromatic pattern substitution. To demonstrate the compatibility of the laccase-mediated oxidation and the alcohol dehydrogenasecatalyzed bioreduction, a deracemization strategy starting from the racemic compounds was developed through a sequential one-pot two-step process, obtaining a selection of $(S)$ - or $(R)$-1-arylprop-2-yn1-ols with excellent yields $(>98 \%)$ and selectivities $(>98 \%$ ee) depending on the alcohol dehydrogenase employed.
\end{abstract}

\section{Introduction}

The oxidation of propargylic alcohols is considered a highly sensitive transformation since the presence of the carbon-carbon triple bond and the alcohol functionality often leads to poor selectivities when employing conventional oxidizing reagents. Traditional oxidative strategies involve the use of metal species or complexes from cobalt, ${ }^{[1]}$ copper, $^{[2]}$ chromium, $^{[3]}$ ruthenium ${ }^{[4]}$

[a] Mr. S. González-Granda, Dr. D. Méndez-Sánchez, Prof. I. Lavandera, Prof. V. Gotor-Fernández

Organic and Inorganic Chemistry Department.

University of Oviedo.

Avenida Julián Clavería 8, 33006 Oviedo, Spain. Phone number: +34985103452 (I.L.); +34985103454 (V.G.F.); fax number: +34985103446 .

E-mail: lavanderaivan@uniovi.es (I.L); vicgotfer@uniovi.es (V.G. F.).

[b] Current address: Dr. D. Méndez-Sánchez

Department of Chemistry

University College London

, 20 Gordon Street, WC1H 0AJ London, UK

Supporting information for this article is given via a link at the end of the document. This file includes comprehensive oxidation and bioreduction studies, EATOS calculations, and full characterization of synthesized alcohols and ketones including also their analytics and NMR spectra. vanadium, ${ }^{[5]}$ or iron, ${ }^{[6]}$ some of them in combination with $\mathrm{N}$-oxide radicals such as $\mathrm{N}$-hydroxyphthalimide ${ }^{[7]}$ or TEMPO and derivatives, ${ }^{[8]}$ and the use of stoichiometric oxidative systems such as the Dess-Martin reagent ${ }^{[9]}$ or manganese oxide. ${ }^{[10]}$ Therefore, the development of sustainable methodologies for the preparation of propargylic ketones under mild reaction conditions is nowadays an area worthy of investigation. Until now, the use of biocatalytic methods for the oxidation of propargylic alcohols remains unexplored, however the applicability of laccases for the previous success in the oxidation of activated substrates such as benzylic ${ }^{[11]}$ and allylic ${ }^{[12]}$ alcohols (Scheme 1a), encouraged us to explore the potential of the catalytic laccase mediator system to produce the corresponding propargylic ketones under mild reaction conditions (Scheme $1 \mathrm{~b}$ ).

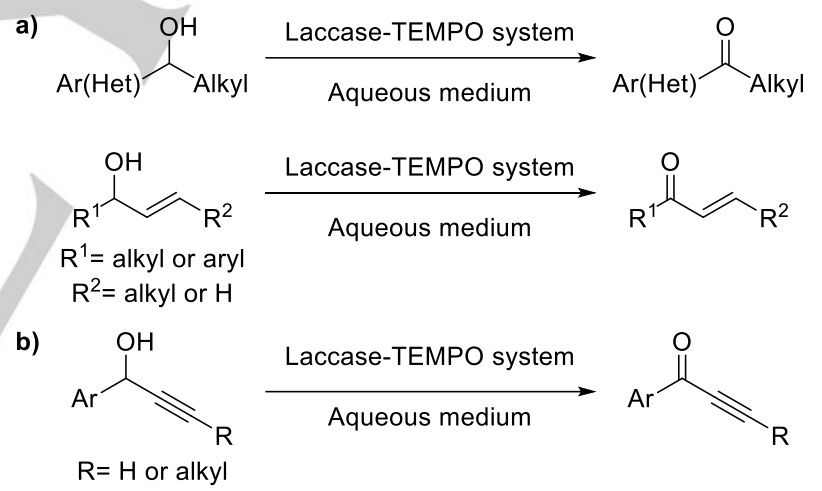

Scheme 1. Use of the laccase-TEMPO system for the: a) previous oxidation of benzylic and allylic alcohols; b) oxidation of propargylic alcohols (this study).

The synthesis of chiral propargylic alcohols represents also an attractive research area for organic chemists since this family of oxygenated compounds are present in numerous biologically active compounds including alkaloids, pheromones, prostaglandins or vitamins, among others, serving at the same time as valuable building blocks for the synthesis of more complex molecules. ${ }^{[13]}$ In the search for sustainable and stereoselective synthesis of this class of compounds, biocatalytic methods have already demonstrated their versatility for the preparation of various families of propargylic alcohol derivatives mainly by using alcohol dehydrogenase (ADH)-catalyzed reductions,,$^{\left[{ }^{14}\right]}$ lipasecatalyzed hydrolytic ${ }^{[15]}$ and transesterification ${ }^{[16]}$ reactions, or even deracemizations experiments using whole cell systems, ${ }^{[17]}$ although there is a lack for a general methodology to provide these valuable compounds. 


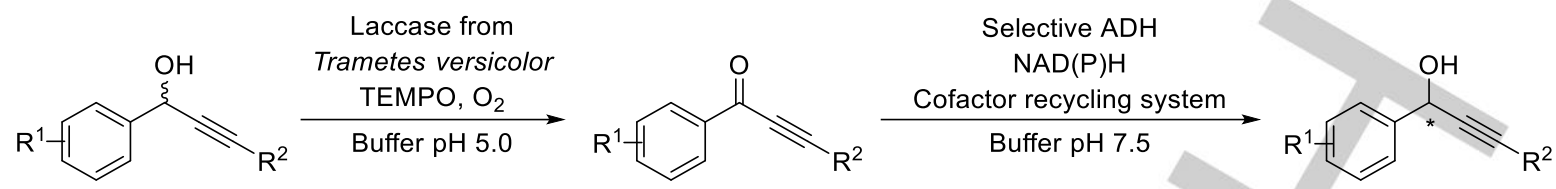

Scheme 2. Chemoenzymatic oxidation of propargylic alcohols via laccase-mediated non selective oxidation followed by stereoselective bioreduction of the propargylic ketone intermediates in order to develop a general strategy for the deracemization of racemic 1-arylprop-2-yn-1-ols.

Herein, we investigate first the design of a general strategy for the oxidation of racemic propargylic alcohols mediated by the laccase-TEMPO system ${ }^{[18]}$ to later explore the bioreduction of the resulting propargylic ketones by alcohol dehydrogenasecatalyzed bioreductions. This will allow the development of deracemization ${ }^{[19]}$ experiments combining both enzymatic methodologies to produce valuable enantiopure alcohols from their racemates in a one-pot two step-process (Scheme 2).

\section{Results and Discussion}

\section{Oxidation of propargylic alcohols}

To evaluate the suitability of the catalytic system composed by the laccase from Trametes versicolor ( $L T V$ ) and the oxy-radical TEMPO, 1-phenylprop-2-yn-1-ol (1a) was selected as model substrate due to its commercial accessibility at low cost. Based on our previous experience in the oxidation of benzylic and allylic alcohols, ${ }^{[11,12]}$ the oxidation of 1a (Table 1) was carried out in a 50 $\mathrm{mM}$ substrate concentration and $30 \mathrm{~mol} \%$ of TEMPO using an oxygenated $50 \mathrm{mM}$ citrate buffer at $\mathrm{pH} 5$ and $10 \% \mathrm{v} / \mathrm{v}$ tert-butyl methyl ether (MTBE) as cosolvent in order to favor the alcohol solubility at $30{ }^{\circ} \mathrm{C}$. Under these conditions, formation of 1 phenylprop-2-yn-1-one (2a) was accomplished in $91 \%$ yield (entry 1), being quantitative transformed after $48 \mathrm{~h}$ (entry 2 ).

Trying to reach complete conversions at shorter reaction times, different parameters were studied including the TEMPO loading, temperature, and the concentration of alcohol $1 \mathrm{a}$ (entries 3-6). The use of a higher amount of TEMPO or the increase of the temperature to $40{ }^{\circ} \mathrm{C}$ led to a partial deactivation of the enzyme and lower recycling rate of the radical TEMPO, achieving then lower conversions $(75-80 \%$, entries 3 and 4). Interestingly, the use or more diluted conditions (25 mM of $\mathbf{1 a}$, entry 5), pleasingly allowed quantitative conversions into ketone $\mathbf{2 a}$, although conversion did not overcome $80 \%$ when reducing the TEMPO loading to $20 \%$, and even after prolonged reaction times (entries 6 and 7).

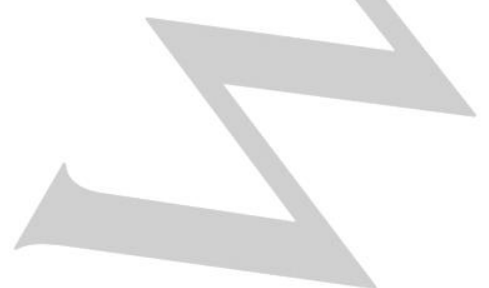

Table 1. Chemoenzymatic oxidation of alcohol 1a using the LTV/TEMPO system. [a]

\begin{tabular}{|c|c|c|c|c|c|}
\hline Entry & [1a] $(\mathrm{mM})$ & TEMPO (mol\%) & $\mathrm{T}\left({ }^{\circ} \mathrm{C}\right)$ & $t(h)$ & $c(\%)^{[b]}$ \\
\hline 1 & 50 & 30 & 30 & 16 & 91 \\
\hline 2 & 50 & 30 & 30 & 48 & $>99$ \\
\hline 3 & 50 & 40 & 30 & 16 & 80 \\
\hline 4 & 50 & 30 & 37 & 16 & 75 \\
\hline 5 & 25 & 30 & 30 & 16 & $>99$ \\
\hline 6 & 25 & 20 & 30 & 16 & 72 \\
\hline 7 & 25 & 20 & 30 & 48 & 79 \\
\hline
\end{tabular}

[a] See a general procedure in the experimental section. [b] Conversion values were determined by GC analysis.

At this point the viability of this chemoenzymatic route was evaluated comparing these results (Table 1, entry 5) with those achieved when using different conventional chemical oxidizing agents such as manganese dioxide $\left(\mathrm{MnO}_{2}\right),{ }^{[10]}$ the Jones reagent or the Dess-Martin reagent ${ }^{[9]}$ (Table 2 ).

Table 2. Oxidation of alcohol 1a through chemical or chemoenzymatic strategies. ${ }^{[a]}$

\begin{tabular}{llll}
\hline Entry & Oxidizing agent & Reaction conditions & $\begin{array}{l}\text { Yield } \\
(\%)^{[\mathrm{bj}]}\end{array}$ \\
\hline 1 & LTV/TEMPO, $\mathrm{O}_{2}$ & Citrate buffer $\mathrm{pH} 5,30^{\circ} \mathrm{C}, 16 \mathrm{~h}$ & 93 \\
2 & $\mathrm{MnO}_{2}$ & $\mathrm{CH}_{2} \mathrm{Cl}_{2}, \mathrm{rt}, 6 \mathrm{~h}$ & 19 \\
3 & Jones reagent & Acetone, rt, 7 h & 35 \\
4 & Dess-Martin reagent & $\mathrm{CH}_{2} \mathrm{Cl}_{2}, \mathrm{rt}, 4 \mathrm{~h}$ & 86 \\
\hline
\end{tabular}

[a] See the experimental section and the ESI file for detailed reaction conditions and procedures. [b] Isolated yields after purification. 
In all cases, several advantages in favor of the LTV/TEMPO system were noticed, not only in the conversions but also in the selectivity of the reactions. For instance, the oxidation of 1a with $\mathrm{MnO}_{2}$ only yielded a $19 \%$ of the ketone (entry 2 ), while the use of a $\mathrm{Cr}(\mathrm{VI})$ species such as the Jones reagent led to a $35 \%$ of the product (entry 3 ), which can be explained due to the formation of multiple by-products, some of them caused by the reactivity of the carbon-carbon triple bond. Finally, the iodine reagent, popularly known as the Dess-Martin reagent, led to the ketone $2 \mathrm{a}$ after $4 \mathrm{~h}$ of reaction with an $86 \%$ yield after purification by column chromatography (entry 4). These results reveal the great sensitivity of propargylic alcohols under typical oxidative conditions, highlighting the use of a chemoenzymatic approach based on two facts, first the complete conversion achieved and second the possibility to work in aqueous medium, which will facilitate the development of concurrent processes such as the alcohol dehydrogenase-catalyzed reduction of the so-obtained ketones.

For these transformations, we performed a simple quantification of the $E$-factor ${ }^{[20]}$ to have an estimation of the environmental impact of these methods. Hence, the EATOS tool ${ }^{[21]}$ was used focusing on waste generated regarding the reaction and isolation auxiliaries (excluding solvents). As can be seen in the ESI (Figure S2), the values obtained clearly favored the chemoenzymatic approach regarding the chemical procedures (between 3.4 and 8.9-times), mainly due to the avoidance of a flash chromatography column.

Next, efforts were devoted to extending the laccase-mediated oxidation to other propargylic alcohols using the reaction conditions previously optimized for $\mathbf{1 a}$. With this purpose, 1phenylbut-2-yn-1-ol (1b) and 1-arylprop-2-yn-1-ols 1c-m were chemically synthesized in moderate to high yields $(53-96 \%$, see full structures in Figure $\mathrm{S} 1$ of the ESI), by reaction of the corresponding benzaldehydes with a slight excess of ethynylmagnesium bromide or prop-1-yn-1-ylmagnesium bromide in dry THF at room temperature. The selection of 11 different benzaldehydes allowed us to obtain the corresponding 1-arylprop-2-yn-1-ols 1c-m with different pattern substitutions on the aromatic ring including electron donating and withdrawing groups to immediately study their oxidations using the LTV/TEMPO system under previously optimized conditions (Table 3).

Regarding the chemoenzymatic oxidation, satisfyingly 1phenylbut-2-yn-1-one $\left(\mathbf{2 b}, \mathrm{R}^{2}=\mathrm{Me}\right.$, entry 2$)$ was produced in quantitative conversion, so the methodology seems applicable for alcohols in the presence of a methyl substituent at the terminal position of the carbon-carbon triple bond. For 1-arylprop-2-yn-1ols bearing monosubstitutions such as the methoxy moiety or a halogen atom on the aromatic ring, the position of these functionalities seemed to do not have a remarkable influence in the reactivity of the LTV/TEMPO system, affording quantitative conversions in all cases when containing a methoxy group (entries 3-5), while when bearing a fluorine atom both the paraand meta-substituted ketones $\mathbf{2 f}$ and $\mathbf{2} \mathbf{g}$ were obtained in $98 \%$ conversion (entries 6 and 7 ). Also excellent results were found when considering the $p$-chloro or o-bromo derivatives $\mathbf{1 h}$ and $\mathbf{1 i}$ (entries 8 and 9), decreasing the conversion to a 93\% when disubstituted alcohol $\mathbf{1} \mathbf{j}$ was used as starting material (entry 10). Finally, high reactivities were also observed when considering additional functional groups including the $p$-methyl, $p$-nitro or a bulkier naphthalene derivative (entries 11-13, 87-97\%).

Table 3. Chemoenzymatic oxidation of racemic propargylic alcohols 1a-n (50 $\mathrm{mM}$ ) using the LTV/TEMPO system. ${ }^{[a]}$

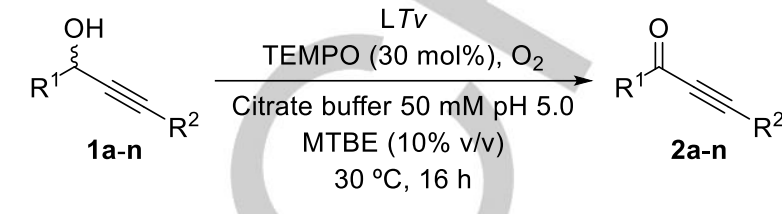

\begin{tabular}{|c|c|c|c|c|}
\hline Entry & Alcohol 1a & $\mathrm{R}^{1}$ & $\mathrm{R}^{2}$ & $c 2 \mathrm{a}-\mathrm{n}(\%)^{[\mathrm{b}]}$ \\
\hline 1 & $1 a$ & $\mathrm{Ph}$ & $\mathrm{H}$ & $>99$ \\
\hline 2 & $1 \mathrm{~b}$ & $\mathrm{Ph}$ & $\mathrm{Me}$ & $>99$ \\
\hline 3 & $1 c$ & 4-OMe- $\mathrm{C}_{6} \mathrm{H}_{4}$ & $\mathrm{H}$ & $>99$ \\
\hline 4 & 1d & 3-OMe- $\mathrm{C}_{6} \mathrm{H}_{4}$ & $\mathrm{H}$ & $>99$ \\
\hline 5 & $1 e$ & 2-OMe- $\mathrm{C}_{6} \mathrm{H}_{4}$ & $\mathrm{H}$ & $>99$ \\
\hline 6 & $1 f$ & 4-F-C $6 \mathrm{H}_{4}$ & $\mathrm{H}$ & 98 \\
\hline 7 & $1 \mathrm{~g}$ & $3-\mathrm{F}-\mathrm{C}_{6} \mathrm{H}_{4}$ & $\mathrm{H}$ & 98 \\
\hline 8 & $1 \mathrm{~h}$ & $4-\mathrm{Cl}-\mathrm{C}_{6} \mathrm{H}_{4}$ & $\mathrm{H}$ & $>99$ \\
\hline 9 & $1 i$ & $2-\mathrm{Br}-\mathrm{C}_{6} \mathrm{H}_{4}$ & $\mathrm{H}$ & $>99$ \\
\hline 10 & $1 \mathrm{j}$ & 2-Br, $5-\mathrm{F}-\mathrm{C}_{6} \mathrm{H}_{3}$ & $\mathrm{H}$ & 93 \\
\hline 11 & $1 \mathrm{k}$ & 4-Me- $\mathrm{C}_{6} \mathrm{H}_{4}$ & $\mathrm{H}$ & 97 \\
\hline 12 & 11 & $4-\mathrm{NO}_{2}-\mathrm{C}_{6} \mathrm{H}_{4}$ & $\mathrm{H}$ & 87 \\
\hline 13 & $1 \mathrm{~m}$ & $2-\mathrm{C}_{10} \mathrm{H}_{7}$ & $\mathrm{H}$ & 94 \\
\hline 14 & $1 \mathrm{n}$ & $\mathrm{PhCH}_{2}$ & $\mathrm{H}$ & 92 \\
\hline
\end{tabular}

[a] See the experimental section for a general procedure. [b] Conversion values were determined by $\mathrm{GC}$ analysis.

To have more information about this synthetic oxidative strategy, an additional substrate 1-phenylbut-3-yn-ol (1n) was included in the study. This compound did not present a double activation as the hydroxyl group is not linked to a benzylic position. Interestingly a high conversion was also attained $(92 \%$, entry 14$)$, showing that in general propargylic alcohols were excellent substrates for the LTV/TEMPO catalytic system. Overall, the chemoenzymatic system resulted more effective than the oxidation using the DessMartin reagent $(51-88 \%$, see Table S1 in the ESI), obtaining conversions over $86 \%$ but in most cases quantitative, isolating the product through a simple liquid-liquid extraction. 


\section{Stereoselective bioreduction of propargylic ketones}

Once that the oxidation of propargylic alcohols 1a-n into the corresponding ketones $\mathbf{2 a}-\mathbf{n}$ was properly addressed, stereoselective bioreductions catalyzed by alcohol dehydrogenases were investigated to produce optically active alcohols. 1-Phenylprop-2-yn-1-one (2a, $25 \mathrm{mM})$ was selected as model substrate and the behavior of a panel of ADHs acting with known opposite stereopreference were tested in bioreduction processes using standard conditions (Tris. $\mathrm{HCl}$ buffer $50 \mathrm{mM} \mathrm{pH}$ 7.5 in the presence of $\mathrm{NAD}(\mathrm{P}) \mathrm{H}(1 \mathrm{mM})$ with $\mathrm{DMSO}$ in $2.5 \% \mathrm{v} / \mathrm{v}$ due to the low solubility of these ketones in aqueous media, $30^{\circ} \mathrm{C}$, $24 \mathrm{~h}$ and $250 \mathrm{rpm}$, Scheme 3). Depending on the selected ADH, isopropanol or the combination of D-glucose and glucose dehydrogenase (GDH) were employed as reducing agents for the required recycling of the nicotinamide cofactor.

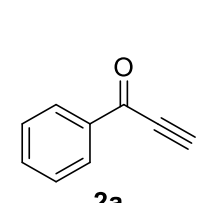

$2 a$
$\mathrm{ADH}$

$\mathrm{NAD}(\mathrm{P}) \mathrm{H}$

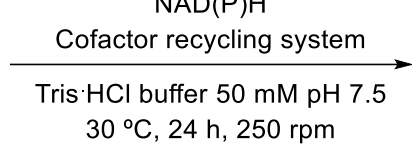

$30{ }^{\circ} \mathrm{C}, 24 \mathrm{~h}, 250 \mathrm{rpm}$

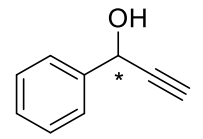

$1 \mathrm{a}$
Scheme 3. Stereoselective bioreduction of 1-phenylprop-2-yn-1-one (2a, 25 $\mathrm{mM}$ ) using ADHs.

As (S)-selective enzymes, lyophilized cells of $E$. coli overexpressing ADHs from Ralstonia species (RasADH), ${ }^{[22]}$ Sphingobium yanoikuyae (SyADH), ${ }^{[23]}$ Thermoanaerobacter species (ADH-T), ${ }^{[24]}$ Thermoanaerobacter ethanolicus $(\mathrm{TeSADH})^{[14 \mathrm{~b}]}$ and Rhodococcus ruber $(\mathrm{ADH}-\mathrm{A})^{[25]}$ were considered, while ADHs from Lactobacillus brevis (LbADH), ${ }^{[26]}$ and commercially available evo-1.1.200 ${ }^{[27]}$ were employed for the production of the $(R)$-alcohol. The results of this screening has been summarized in Table S2 of the ESI, finding the best results with RasADH, usually an enzyme that accepts sterically hindered substrates, ${ }^{[28}$ which gave access to $(S)-1$ a in quantitative conversion and enantiopure form, while $(R)$-1a was obtained in $90 \%$ conversion and $>99 \%$ ee using evo-1.1.200. On the basis of this preliminary screening, the bioreductions of ketones $\mathbf{2 b}-\mathbf{n}$ were rushed using the RasADH and evo-1.1.200 enzymes (Table 4).

Satisfyingly, in all cases excellent conversions were achieved (97$>99 \%$ conversion). On the one hand, when using RasADH, (S)-1- phenylbut-3-yn-ols (1a,c-m) were obtained in very high to excellent selectivities (93->99\% ee, entries 1,3-13). The selectivity decreased when considering the alcohol $1 \mathrm{~b}$ with a methyl moiety at the propargylic position ( $85 \%$ ee, entry 2 ) was obtained, and this enzyme did not act with any preference towards the alkyl derivative $\mathbf{2 n}$ (entry 14). On the other hand, the $(R)$ alcohols were preferentially obtained with different degree of selectivity employing evo-1.1.200. In general, the alcohol optical purities ranged from high to excellent ( $88->99 \%$ ee), except when considering electron-donating groups as the methoxy at different positions of the aromatic ring (1c-e, $62-73 \%$ ee, entries $3-5$ ), or sterically hindered $o$-brominated derivatives $1 \mathbf{i}$ and $1 \mathbf{j}(21-34 \%$ ee, entries 9 and 10) affording preferentially the (S)-enantiomers in these last two examples. Finally, the alcohol $(S)$-1n was obtained due to a switch in the Cahn-Ingold-Prelog (CIP) priority of the substituents.

\section{Chemoenzymatic deracemization of propargylic alcohols}

Based on the high activity displayed by the LTV/TEMPO catalytic system and the stereoselectivity shown by complementary ADHs, the development of a one-pot two-step deracemization process of those racemic alcohols presenting the best reactivities and selectivities was investigated. So far, the design of biocatalytic deracemizations has been less explored in comparison with kinetic resolutions and desymmetrizations, ${ }^{[19]}$ being just reported an example implying propargylic alcohols using a microorganism as whole cell system. ${ }^{[17]}$ In an ideal deracemization approach, this methodology will allow the production of enantiopure alcohols from their racemic forms, although the different reaction conditions (i.e., $\mathrm{pH}$ ) required for the oxidation and bioreduction steps must be considered in the current case. Also, the occurrence of oxidative conditions obviously hampers the performance of the selective reduction. In addition, it has been described that the laccase-TEMPO system can oxidize monoand disaccharides at the primary alcohol position, being not possible the use of the glucose and glucose dehydrogenase pair for cofactor recycling purposes. ${ }^{[12,29]}$ For these reasons, the optimization of a one-pot sequential approach was considered from the beginning, again considering 1-phenylprop-2-yn-1-ol (1a) and 1-phenylprop-2-yn-1-one (2a) as model substrates for individual reaction optimizations. 
Table 4. Stereoselective bioreduction of propargylic ketones $2 \mathrm{a}-\mathbf{n}(25 \mathrm{mM})$ using RasADH and evo-1.1.200 at $30{ }^{\circ} \mathrm{C}$ for $24 \mathrm{~h}$ at $250 \mathrm{rpm}$. ${ }^{\text {aa] }}$

\begin{tabular}{|c|c|c|c|c|c|c|c|}
\hline \multirow{3}{*}{ Entry } & \multirow{3}{*}{ Ketone } & $\mathrm{R}^{1}$ & $\begin{array}{l}\text { Sofacto } \\
\text { s. } \mathrm{HCl} \\
30^{\circ} \mathrm{C}\end{array}$ & $\underset{7.5}{\stackrel{n}{\longrightarrow}}$ & & 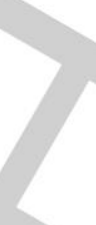 & \\
\hline & & $\mathrm{R}^{1}$ & $\mathrm{R}^{2}$ & & $\mathrm{ADH}$ & & 200 \\
\hline & & & & $c(\%)^{[b]}$ & $e e(\%)^{[c]}$ & $c(\%)^{[b]}$ & $e e(\%)^{[c]}$ \\
\hline 1 & $2 a$ & $\mathrm{Ph}$ & $\mathrm{H}$ & $>99$ & $>99$ & $>99$ & $>99$ \\
\hline 2 & $2 b$ & $\mathrm{Ph}$ & $\mathrm{Me}$ & $>99$ & 85 & $>99$ & 88 \\
\hline 3 & $2 c$ & 4-OMe- $\mathrm{C}_{6} \mathrm{H}_{4}$ & $\mathrm{H}$ & $>99$ & $>99$ & 97 & 73 \\
\hline 4 & $2 d$ & 3-OMe- ${ }_{6} \mathrm{H}_{4}$ & $\mathrm{H}$ & $>99$ & $>99$ & $>99$ & 62 \\
\hline 5 & $2 e$ & 2-OMe- $\mathrm{C}_{6} \mathrm{H}_{4}$ & $\mathrm{H}$ & $>99$ & $>99$ & $>99$ & 63 \\
\hline 6 & $2 f$ & $4-\mathrm{F}-\mathrm{C}_{6} \mathrm{H}_{4}$ & $\mathrm{H}$ & $>99$ & 95 & $>99$ & 99 \\
\hline 7 & $2 \mathrm{~g}$ & $3-\mathrm{F}-\mathrm{C}_{6} \mathrm{H}_{4}$ & $\mathrm{H}$ & $>99$ & 99 & $>99$ & $>99$ \\
\hline 8 & $2 \mathrm{~h}$ & $4-\mathrm{Cl}-\mathrm{C}_{6} \mathrm{H}_{4}$ & $\mathrm{H}$ & $>99$ & 98 & $>99$ & 99 \\
\hline 9 & $2 \mathbf{i}$ & $2-\mathrm{Br}-\mathrm{C}_{6} \mathrm{H}_{4}$ & $\mathrm{H}$ & $>99$ & $>99$ & $>99$ & $34^{[d]}$ \\
\hline 10 & $2 j$ & $2-\mathrm{Br}, 5-\mathrm{F}-\mathrm{C}_{6} \mathrm{H}_{3}$ & $\mathrm{H}$ & $>99$ & 95 & 98 & $21^{[d]}$ \\
\hline 11 & $2 k$ & 4-Me- $\mathrm{C}_{6} \mathrm{H}_{4}$ & $\mathrm{H}$ & 98 & 98 & $>99$ & $>99$ \\
\hline 12 & 21 & $4-\mathrm{NO}_{2}-\mathrm{C}_{6} \mathrm{H}_{4}$ & $\mathrm{H}$ & $>99$ & 88 & $>99$ & $>99$ \\
\hline 13 & $2 m$ & 2- $\mathrm{C}_{10} \mathrm{H}_{7}$ & $\mathrm{H}$ & $>99$ & 97 & $>99$ & 89 \\
\hline 14 & $2 n$ & $\mathrm{PhCH}_{2}$ & $\mathrm{H}$ & 99 & $<3$ & $>99$ & $>99^{[e]}$ \\
\hline
\end{tabular}

[a] See the experimental section for a general procedure. [b] Conversion values of the bioreduction processes were determined by GC analysis. [c] Enantiomeric excess of alcohols 1a-n were determined by GC analysis, RasADH leading to the (S)-enantiomers and evo-1.1.200 to their $(R)$-antipodes. [d] The ( $S$ )-enantiomer was preferentially obtained. [e] The $(S)$-enantiomer was obtained due to a switch in the CIP rule priority.

At this point is necessary to overcome that each enzyme effectively works at different $\mathrm{pH}$ values (acidic for the laccase and slightly basic conditions for the ADH). To start, the use of $50 \mathrm{mM}$ alcohol concentration is advisable for the laccase-mediated oxidation (Table 1, entry 4) while $25 \mathrm{mM}$ is ideal for the bioreduction step (Table 4). This fact obviously must be also transferred to the use of different buffer compositions (citrate buffer for the oxidation and $\mathrm{Tris} \cdot \mathrm{HCl}$ for the reduction). For all these issues, the bioreductions of ketone $2 \mathrm{a}$ using RasADH and evo-1.1.200 were next deeply studied (see Table S3 in the ESI). The reduction of $2 \mathbf{a}$ was attempted using different substrate concentrations ( 25 and $50 \mathrm{mM}$ ), buffer compositions (Tris $\mathrm{HCl}$ and citrate) and $\mathrm{pH}$ values $(5.0,6.5$ and 7.5$)$, observing in all cases $99 \%$ conversion. For RasADH in Tris $\mathrm{HCl}$ buffer, the use of a higher ketone concentration led to a decrease in the selectivity ( $86 \%$ ee at $50 \mathrm{mM},>99 \%$ ee at $25 \mathrm{mM}$ ) and a similar effect was observed using the same concentration but a lower $\mathrm{pH}(89 \%$ ee at $25 \mathrm{mM}$ and $\mathrm{pH}$ 6.5). Interestingly, very high selectivities were observed in the same aqueous medium employed in the laccase- catalyzed reaction (96-97\% ee at pH 5.0 in both 25 and $50 \mathrm{mM}$ ). Additionally, evo-1.1.200 displayed excellent selectivity at 25-50 $\mathrm{mM}$ and $\mathrm{pH} 6.5-7.5$ ( $>98 \%$ ee), while moderate ee values were observed when using a citrate buffer pH 5.0 (79 and 68\% ee at 25 and $50 \mathrm{mM}$, respectively).

The sequential approach was then addressed changing the ketone intermediate concentration and/or the $\mathrm{pH}$ of the reaction once the racemic alcohol 1a was completely transformed into ketone $2 \mathrm{a}$ after $16 \mathrm{~h}$ reaction at $30^{\circ} \mathrm{C}$ in the citrate buffer $50 \mathrm{mM}$ $\mathrm{pH} 5.0$ with $10 \% \mathrm{v} / \mathrm{v}$ DMSO (Table 5). Firstly, at $25 \mathrm{mM}$ substrate concentration, it was found that RasADH dramatically lost most of the activity, reaching only $27 \%$ conversion in the bioreduction process (entry 1), while evo-1.1.200 catalyzed the reaction almost to completion and with just a small loss of the selectivity (entry 2). 
Table 5. Deracemization of 1a under different reaction conditions. ${ }^{[a]}$

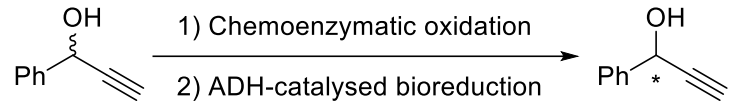

$$
\begin{aligned}
& \text { rac-1a }
\end{aligned}
$$

\begin{tabular}{llllll}
\hline Entry & {$[\mathbf{1 a}](\mathrm{mM})$} & Final pH & ADH & $c(\%)^{[\mathrm{b}]}$ & ee $(\%)^{[\mathrm{b}]}$ \\
\hline 1 & 25 & 5.0 & Ras & 27 & n.d. \\
2 & 25 & 5.0 & evo-1.1.200 & 98 & $93(R)$ \\
\hline 3 & 50 & $6.1^{[\mathrm{c}]}$ & Ras & 17 & n.d. \\
4 & 50 & $6.1^{[\mathrm{c}]}$ & evo-1.1.200 & 88 & $94(R)$ \\
\hline 5 & 25 & $8.0^{[\mathrm{d}]}$ & Ras & 99 & $99(S)$ \\
6 & 25 & $8.0^{[\mathrm{d}]}$ & evo-1.1.200 & 98 & $99(R)$ \\
\hline 7 & 50 & $7.5^{[\mathrm{e}]}$ & Ras & 99 & $99(S)$ \\
\hline 8 & 50 & $7.5^{[\mathrm{e}]}$ & evo-1.1.200 & 94 & $97(R)$ \\
\hline
\end{tabular}

[a] See the experimental section for detailed reaction conditions and a general procedure. [b] Conversion (regarding the ketone intermediate) and enantiomeric excess values of $\mathbf{1 a}$ were determined by GC analysis. In parentheses the major alcohol enantiomer appears. [c] pH value obtained after the addition of Tris $\mathrm{HCl}$ buffer $\mathrm{pH} 7.5$ to obtain a $25 \mathrm{mM}$ ketone concentration. [d] $30 \mu \mathrm{L}$ of $\mathrm{NaOH} 3 \mathrm{M}$ were added. [e] $\mathrm{pH}$ value obtained after the addition of Tris $\mathrm{HCl}$ buffer $\mathrm{pH} 7.5$ to obtain a $25 \mathrm{mM}$ ketone concentration and additional $30 \mu \mathrm{L}$ of $\mathrm{NaOH} 3 \mathrm{M}$. n.d.: Not determined.

Similar results were achieved when starting from $50 \mathrm{mM}$ of $\mathbf{1 a}$ and diluting the ketone intermediate up to $25 \mathrm{mM}$ by addition of Tris $\mathrm{HCl}$ buffer $\mathrm{pH} 7.5$, thus increasing the $\mathrm{pH}$ value until 6.1 (entries 3 and 4). Remarkably excellent results with both ADHs were attained in terms of conversion and optical purities towards 1a (25 mM, entries 5 and 6), when after the oxidation step a unique addition of $30 \mu \mathrm{L}$ of a NaOH $3 \mathrm{M}$ aqueous solution was achieved, elevating the $\mathrm{pH}$ until 8.1. Finally, successful experiments were also attained in the process at $50 \mathrm{mM}$ substrate concentration and diluting in the middle stage with the Tris $\mathrm{HCl}$ buffer $\mathrm{pH} 7.5$ and extra addition of $\mathrm{NaOH} 3 \mathrm{M}$ (entries 7 and 8). Once demonstrated the deracemization of racemic alcohol 1a using complementary ADHs (Table 6, entries 1 and 2), and based on the excellent reactivity in the chemoenzymatic oxidation of racemic methoxy substituted alcohols 1c-e and o-bromoderivative $\mathbf{1} \mathbf{i}$, and the bioreduction of the corresponding ketones 2c-e,i using RasADH as biocatalyst, the deracemization of alcohols 1c-e,i was successfully developed, yielding with complete conversions and excellent selectivities the corresponding (S)-alcohols (entries 3-6). Finally, the deracemization of 1a was scaled-up at $50 \mathrm{mg}$ using RasADH or evo-1.1.200 affording both 1a enantiomers in $98 \%$ ee and high isolated yields after column chromatography on silica gel, $83 \%$ for the $(S)$-alcohol and $79 \%$ for its $(R)$-antipode.
Table 6. Deracemization of 1a,c-e,i using RasADH and evo-1.1200. ${ }^{[a]}$

\begin{tabular}{lllll}
\hline Entry & Alcohol & ADH & $c(\%)^{[b]}$ & ee $(\%)^{[b]}$ \\
\hline 1 & 1a $(H)$ & Ras & 99 & $>99(S)$ \\
2 & 1a $(H)$ & evo-1.1.200 & 98 & $>99(R)$ \\
\hline 3 & 1c $(4-\mathrm{OMe})$ & Ras & $>99$ & $>99(S)$ \\
4 & 1d $(3-\mathrm{OMe})$ & Ras & $>99$ & $>99(S)$ \\
5 & 1e $(2-\mathrm{OMe})$ & Ras & $>99$ & $>99(S)$ \\
6 & $\mathbf{1 i}(2-\mathrm{Br})$ & Ras & $>99$ & $99(S)$ \\
\hline
\end{tabular}

[a] See the experimental section for detailed reaction conditions and a general procedure. [b] Conversion (regarding the ketone intermediate) and enantiomeric excess values of $\mathbf{1 a}, \mathbf{c}-\mathbf{e}, \mathbf{i}$ were determined by $\mathrm{GC}$ analysis.

\section{Conclusions}

A mild and chemoselective oxidation of propargylic alcohols has been described by the combined action of a catalytic system composed by the laccase from Trametes versicolor and the oxyradical TEMPO, which was able to oxidize 14 racemic alcohols in very high to quantitative conversions (87->99\%). This strategy has been compared with traditional oxidizing agents such as manganese(IV) oxide, Jones or Dess-Martin reagents, improving or achieving comparable results in terms of selectivity and yields. Remarkably, the laccase-mediated oxidation has been proved to be a sustainable oxidative method for the production of propargylic ketones as demonstrated by a simple quantification of the E-factor using the EATOS tool regarding other traditional oxidative methods. Moreover, bioreduction of the corresponding ketones was studied, screening different alcohol dehydrogenases commercially available or made in house and overexpressed in $E$. coli. The best results were found with the ADH from Ralstonia species and evo-1.1.200, which allowed the production of the $(S)$ 1-arylprop-2-yn-1-ols (1a-m, $>98 \%$ conv., $>85 \%$ ee) and the $(R)$ alcohols (1b,c,f-h,k-n, $>97 \%$ conv., $>88 \%$ ee), respectively. Taking advantage of the development of both biotransformations in aqueous medium, we decided to explore the possibilities to carry out a sequential one-pot two-step deracemization protocol of some of these substrates. For this concurrent process, changing the $\mathrm{pH}$ was necessary from 5.0 , the best one for the laccase action, to 7.5 where the ADH is able to display high activity. Hence, the deracemization of four 1-arylprop-2-yn-1-ols was successfully achieved to produce the corresponding optically active alcohols in excellent yields and selectivities, demonstrating the scalability of the process at semi-preparative scale. 


\section{Experimental Section}

Materials. Chemical reagents for the chemical synthesis of alcohols 1a-n and ketones 2a-n were purchased from Sigma-Aldrich. Laccase from Trametes versicolor (LTv, $0.5 \mathrm{U} / \mathrm{mg})$, glucose, NADH and NADPH were also acquired from Sigma-Aldrich, while glucose dehydrogenase (GDH105) was obtained from Codexis Inc. to develop the biotransformations. For the chemoenzymatic oxidations, citrate buffer $50 \mathrm{mM} \mathrm{pH} 5.0$ was previously oxygenated by bubbling molecular oxygen using a balloon for at least 30 minutes. Sequential reactions were performed in a microwave tube $[(19 \times 130 \times 3) \mathrm{mm}]$. The oxidation step mediated by the laccaseTEMPO catalytic system was performed open-to-air, while for the bioreduction step, the microwave tube was closed. Lyophilized $E$. coli/RasADH cells were obtained as previously described in the bibliography, ${ }^{[28]}$ and evo-1.1.200 was purchased from Evoxx technologies. NMR spectra $\left({ }^{1} \mathrm{H},{ }^{13} \mathrm{C}\right.$ and ${ }^{19} \mathrm{~F}$ NMR) were recorded on a Bruker AV300 $\mathrm{MHz}$ spectrometer. All chemical shifts $(\delta)$ are given in parts per million (ppm). Gas chromatography (GC) analyses were performed on an Agilent HP6890 GC chromatograph equipped with a FID detector. Highperformance liquid chromatography (HPLC) analyses were carried out in in a Hewlett Packard 1100 chromatograph equipped with a VIS-UV detector. Thin-layer chromatography (TLC) was conducted with Merck Silica Gel 60 F254 precoated plates and visualized with UV, potassium permanganate and vanillin stain. Column chromatographies were performed using silica gel 60 (230-240 mesh). Melting points were taken on samples in open capillary tubes and are uncorrected. High resolution mass spectra (HRMS) experiments were carried out by $\mathrm{ESI}^{+}$using a Micro Tof $Q$ spectrometer.

General procedure for the chemical synthesis of racemic propargylic alcohols 1a-n. To a solution of the corresponding benzaldehyde $(5 \mathrm{mmol})$ in dry $\mathrm{THF}(2.5 \mathrm{~mL})$ at $0^{\circ} \mathrm{C}$ and under argon atmosphere, a $0.5 \mathrm{M}$ solution of ethynylmagnesium bromide or prop-1-yn-1-ylmagnesium bromide in dry THF (11 mL, $5.50 \mathrm{mmol})$ was added. The mixture was stirred at $0{ }^{\circ} \mathrm{C}$ for 4 $\mathrm{h}$ and after this time, the reaction was quenched by the addition of a saturated $\mathrm{NH}_{4} \mathrm{Cl}$ aqueous solution $(10 \mathrm{~mL})$. The solvent was removed under vacuum, and the mixture extracted with $\mathrm{CH}_{2} \mathrm{Cl}_{2}(3 \times 10 \mathrm{~mL})$. The combined organic phases were washed with a saturated $\mathrm{NaCl}$ aqueous solution $(2 \times 10 \mathrm{~mL})$, dried over $\mathrm{Na}_{2} \mathrm{SO}_{4}$, filtered and concentrated under vacuum. Reaction crudes were purified by column chromatography on silica gel, obtaining the corresponding racemic propargylic alcohols 1a-n (53-96\%). See the Electronic Supporting Information for details related to the full characterization of synthesized alcohols.

General procedure for the chemical oxidation of propargylic alcohols 1a-n with the Dess-Martin reagent. To a solution of propargylic alcohol 1a-n (2.27 mmol) in $\mathrm{CH}_{2} \mathrm{Cl}_{2}(22.7 \mathrm{~mL}$ ) placed in a round bottom-flask, the Dess-Martin reagent $(1.4 \mathrm{~g}, 3.2 \mathrm{mmol})$ was added and the reaction stirred at room temperature. The reaction was followed by TLC analyses, observing the consumption of the starting material after $4 \mathrm{~h}$. After this time, a $50 \%$ v/v aqueous solution of $\mathrm{NaHCO}_{3} / \mathrm{Na}_{2} \mathrm{~S}_{2} \mathrm{O}_{3}$ was added, and then extracted with $\mathrm{CH}_{2} \mathrm{Cl}_{2}(3 \times 15 \mathrm{~mL})$. The organic phases were combined and dried over anhydrous $\mathrm{Na}_{2} \mathrm{SO}_{4}$, filtered and the solvent finally removed under vacuum. The reaction crude was purified by column chromatography on silica gel (30\% EtOAc/Hexane), obtaining the corresponding propargylic ketones 2a-n (51-88\% yield). See the Electronic Supporting Information for details related to the full characterization of synthesized ketones.
General procedure for the chemoenzymatic oxidation of propargylic alcohols 1a-n using the catalytic system composed by the laccase from Trametes versicolor and the oxy-radical TEMPO. In a microwave tube open to the air, the corresponding racemic propargylic alcohol 1a-n $(0.05 \mathrm{mmol})$, MTBE $(200 \mu \mathrm{L}, 10 \% \mathrm{v} / \mathrm{v})$ and a previously oxygenated citrate buffer $50 \mathrm{mM} \mathrm{pH} 5.0(2 \mathrm{~mL})$ were added. Next, the laccase from Trametes versicolor (10 mg, $5 \mathrm{U}$ ) and TEMPO $(2.40 \mathrm{mg}, 0.015 \mathrm{mmol})$ were added, and the mixture reacted for $16 \mathrm{~h}$ with magnetic stirring at $30{ }^{\circ} \mathrm{C}$. After this time, the mixture was extracted with EtOAc $(3 \times 1 \mathrm{~mL})$, the organic layers combined, dried over anhydrous $\mathrm{Na}_{2} \mathrm{SO}_{4}$ and filtered. The solution was finally concentrated, and the conversion values measured by GC analyses. General procedure for the bioreduction of propargylic ketones $2 a-n$ using RasADH. To a $1.5 \mathrm{~mL}$-Eppendorf tube containing the corresponding propargylic ketone 2a-n (0.015 mmol), DMSO (75 $\mu \mathrm{L})$, a solution of $\mathrm{GDH}(60 \mu \mathrm{L}, 10 \mathrm{U})$, an aqueous solution of D-glucose $(60 \mu \mathrm{L}$, $500 \mathrm{mM})$, an aqueous solution of NADPH $(60 \mu \mathrm{L}, 10 \mathrm{mM})$, buffer Tris. $\mathrm{HCl}$ $\mathrm{pH} 7.5(345 \mu \mathrm{L}, 50 \mathrm{mM})$ and lyophilized cells of $E$. coli overexpressing RasADH (12 mg) were successively added. Then, the Eppendorf tube was closed and kept under orbital shaking at $250 \mathrm{rpm}$ at $30^{\circ} \mathrm{C}$ for $24 \mathrm{~h}$. After this time, the solution was extracted with EtOAc $(3 \times 0.5 \mathrm{~mL})$, the organic layers combined, dried over anhydrous $\mathrm{Na}_{2} \mathrm{SO}_{4}$ and filtered. The resulting solution was concentrated, measuring the conversion and the enantiomeric excess values of alcohols (S)-1a-n by GC analyses.

General procedure for the bioreduction of propargylic ketones $2 a-n$ using evo-1.1.200. To a $1.5 \mathrm{~mL}$-Eppendorf tube containing the corresponding propargylic ketone 2a-n (0.0125 mmol), DMSO (56 $\mu \mathrm{L})$, i $\mathrm{PrOH}(25 \mu \mathrm{L})$, an aqueous solution of $\mathrm{MgCl}_{2}(50 \mu \mathrm{L}, 10 \mathrm{mM})$, an aqueous solution of NADH $(50 \mu \mathrm{L}, 10 \mathrm{mM})$, buffer Tris. HCl pH $7.5(319 \mu \mathrm{L}, 50 \mathrm{mM})$ and evo-1.1.200 (12 mg) were successively added. Then, the Eppendorf tube was closed and kept under orbital shaking at $250 \mathrm{rpm}$ at $30^{\circ} \mathrm{C}$ for 24 h. After this time, the solution was extracted with EtOAc $(3 \times 0.5 \mathrm{~mL})$, the organic layers combined, dried over anhydrous $\mathrm{Na}_{2} \mathrm{SO}_{4}$ and filtered. The resulting solution was concentrated, measuring the conversion and the enantiomeric excess values of alcohols $(R)-1 \mathbf{a}-\mathbf{n}$ by GC analyses.

General procedure for the deracemization of propargylic alcohols 1a,c-e,i using the laccase from Trametes versicolor, TEMPO and RasADH in analytical scale. To a solution of the corresponding racemic propargylic alcohol 1a,c-e,i $(0.05 \mathrm{mmol})$ in a previously oxygenated citrate buffer $50 \mathrm{mM} \mathrm{pH} 5.0(2 \mathrm{~mL})$ and MTBE $(200 \mu \mathrm{L}, 10 \% \mathrm{v} / \mathrm{v})$ inside a microwave tube $(19 \times 130 \times 3 \mathrm{~mm})$ open to the air, the laccase from Trametes versicolor (10 mg, $5 \mathrm{U}$ ) and TEMPO (2.40 mg, $0.015 \mathrm{mmol})$ were added. The mixture reacted for $16 \mathrm{~h}$ with magnetic stirring at $30{ }^{\circ} \mathrm{C}$. After this time, the following reagents were added: $\mathrm{GDH}(240 \mu \mathrm{L}, 40 \mathrm{U})$, an aqueous solution of D-glucose $(240 \mu \mathrm{L}, 500 \mathrm{mM})$, an aqueous solution of $\mathrm{NADPH}(240 \mu \mathrm{L}, 10 \mathrm{mM})$, an aqueous solution of $\mathrm{NaOH} 3 \mathrm{M}(16.25 \mu \mathrm{L})$ to adjust the $\mathrm{pH}$ to a value between 7.5 and 8.0, and lyophilized cells of $E$. coli overexpressing RasADH (12 mg). The microwave tube was closed and orbitally shaken at $250 \mathrm{rpm}$ and $30^{\circ} \mathrm{C}$ for $24 \mathrm{~h}$. After this time, the mixture was extracted with EtOAc $(3 \times 0.5 \mathrm{~mL})$, combining the organic layers, which were dried over anhydrous $\mathrm{Na}_{2} \mathrm{SO}_{4}$ and filtered. Then, the solution was concentrated and the conversion and the enantiomeric excess values of the propargylic alcohols were measured by GC analyses. 
General procedure for the deracemization of propargylic alcohol 1a using the laccase from Trametes versicolor, TEMPO and evo-1.1-200 in analytical scale. To a solution of the corresponding racemic propargylic alcohol $1 \mathrm{a}(0.05 \mathrm{mmol})$ in a previously oxygenated citrate buffer $50 \mathrm{mM} \mathrm{pH}$ $5.0(2 \mathrm{~mL})$ and MTBE $(200 \mu \mathrm{L}, 10 \% \mathrm{v} / \mathrm{v})$ inside a microwave tube $(19 \times 130$ $x 3 \mathrm{~mm}$ ) open to the air, the laccase from Trametes versicolor (10 mg, 5 $\mathrm{U})$ and TEMPO $(2.40 \mathrm{mg}, 0.015 \mathrm{mmol})$ were added. The mixture reacted for $16 \mathrm{~h}$ with magnetic stirring at $30^{\circ} \mathrm{C}$. After this time, the following reagents were added: $\mathrm{PrOH}(250 \mu \mathrm{L})$, an aqueous solution of $\mathrm{MgCl}_{2}(250$ $\mu \mathrm{L}, 10 \mathrm{mM})$, an aqueous solution of $\mathrm{NADH}(250 \mu \mathrm{L}, 10 \mathrm{mM})$, an aqueous solution of $\mathrm{NaOH} 3 \mathrm{M}(16.25 \mu \mathrm{L})$ to adjust the $\mathrm{pH}$ to a value between 7.5 and 8.0, and evo-1.1.200 (12 mg). Then, the tube was closed and kept under orbital shaking at $250 \mathrm{rpm}$ at $30^{\circ} \mathrm{C}$ for $24 \mathrm{~h}$. After this time, the mixture was extracted with EtOAc $(3 \times 0.5 \mathrm{~mL})$, combining the organic layers, which were dried over anhydrous $\mathrm{Na}_{2} \mathrm{SO}_{4}$ and filtered. Then, the solution was concentrated and the conversion and the enantiomeric excess values of 1 a were measured by GC analyses.

General procedure for the deracemization of 1-phenylprop-2-yn-1-ol (1a) using the laccase from Trametes versicolor, TEMPO and RasADH at semi-preparative scale. To a solution of racemic alcohol 1a $(0.35$ $\mathrm{mmol})$ in a previously oxygenated citrate buffer $50 \mathrm{mM} \mathrm{pH} 5.0(14 \mathrm{~mL})$ and MTBE $(1.4 \mathrm{~mL}, 10 \% \mathrm{v} / \mathrm{v})$ inside a microwave tube $(19 \times 130 \times 3 \mathrm{~mm})$ open to the air, the laccase from Trametes versicolor ( $48 \mathrm{mg}, 24 \mathrm{U}$ ) and TEMPO (16.50 $\mathrm{mg}, 0.105 \mathrm{mmol}$ ) were added. The mixture reacted for $16 \mathrm{~h}$ with magnetic stirring at $30{ }^{\circ} \mathrm{C}$. After this time, the following reagents were added: $\mathrm{GDH}$ (1.4 mL, $233 \mathrm{U}$ ), an aqueous solution of D-glucose $(1.4 \mathrm{~mL}$, $50 \mathrm{mM}$ ), an aqueous solution of NADPH (1.4 mL, $10 \mathrm{mM})$, an aqueous solution of $\mathrm{NaOH} 3 \mathrm{M}(113.5 \mu \mathrm{L})$ to adjust the $\mathrm{pH}$ to a value between 7.5 and 8.0, and lyophilized cells of E. coli overexpressing RasADH (82 mg). The microwave tube was closed and orbitally shaken at $250 \mathrm{rpm}$ and $30^{\circ} \mathrm{C}$ for $24 \mathrm{~h}$. After this time, the mixture was extracted with EtOAc $(3 \times 3 \mathrm{~mL})$, combining the organic layers, which were dried over anhydrous $\mathrm{Na}_{2} \mathrm{SO}_{4}$ and filtered. Then, the solution was concentrated and the conversion and the enantiomeric excess values of (S)-1a were measured by GC analyses. The product was finally purified by column chromatography on silica gel (30\% EtOAc/Hexane), obtaining the alcohol (S)-1a in $83 \%$ isolated yield and $98 \%$ ee.

General procedure for the deracemization of 1-phenylprop-2-yn-1-ol (1a) using the laccase from Trametes versicolor, TEMPO and evo1.1.200 at semi-preparative scale. To a solution of the corresponding racemic propargylic alcohol $1 \mathrm{a}(0.35 \mathrm{mmol})$ in a previously oxygenated citrate buffer $50 \mathrm{mM} \mathrm{pH} 5.0(14 \mathrm{~mL})$ and MTBE $(1.4 \mathrm{~mL}, 10 \% \mathrm{v} / \mathrm{v})$ inside a microwave tube $(19 \times 130 \times 3 \mathrm{~mm})$ open to the air, the laccase from Trametes versicolor (48 mg, $24 \mathrm{U}$ ) and TEMPO (16.50 mg, $0.105 \mathrm{mmol}$ ) were added. The mixture reacted for $16 \mathrm{~h}$ with magnetic stirring at $30^{\circ} \mathrm{C}$. After this time, the following reagents were added: $\mathrm{PrOH}(788 \mu \mathrm{L})$, an aqueous solution of $\mathrm{MgCl}_{2}(1.55 \mathrm{~mL}, 10 \mathrm{mM})$, an aqueous solution of $\mathrm{NADH}(1.55 \mathrm{~mL}, 10 \mathrm{mM})$, an aqueous solution of $\mathrm{NaOH} 3 \mathrm{M}(113.5 \mu \mathrm{L})$ to adjust the $\mathrm{pH}$ to a value between 7.5 and 8.0 , and evo-1.1.200 (80 mg). After this time, the mixture was extracted with EtOAc $(3 \times 3 \mathrm{~mL})$, combining the organic layers, which were dried over anhydrous $\mathrm{Na}_{2} \mathrm{SO}_{4}$ and filtered. Then, the solution was concentrated and the conversion and the enantiomeric excess values of $(R)-\mathbf{1 a}$ were measured by $\mathrm{GC}$ analyses. The product was finally purified by column chromatography on silica gel (30\% EtOAc/Hexane), obtaining the alcohol $(R)-1 \mathrm{a}$ in $79 \%$ isolated yield and $98 \%$ ee.

\section{Acknowledgements}

Financial supports from the Spanish Ministry of Economy and Competitiveness (MEC, Project CTQ2016-75752-R) and the Asturian Regional Government (FC-GRUPIN-IDI/2018/000181) are gratefully acknowledged. We thank Prof. Wolfgang Kroutil (University of Graz, Austria) for providing us with alcohol dehydrogenases overexpressed in E. coli cells.

Keywords: Bioreduction • Deracemization • Laccases • Oxidation • Propargylic alcohols

[1] a) V. B. Sharma, S. L. Jain, B. Sain, Tetrahedron Lett. 2003, 44, 383 386; b) G. Blay, L. Cardona, I. Fernández, J. R. Pedro, Synthesis 2007, 3329-3332.

[2] a) C. Han, M. Yu, W. Sun, X. Yao, Synlett 2011, 2363-2368; b) K. C. Weerasiri, A. E. V. Gorden, Eur. J. Org. Chem. 2013, 1546-1550; c) W. Lv, J. Tian, N. Deng, Y. Wang, X. Zhu, X. Yao, Tetrahedron Lett. 2015, $56,1312-1316$.

[3] a) L. S. van de Vondervoort, S. Bouttemy, J. M. Padrón, J. L. Bras, J. Muzart, P. L. Alsters, Synlett 2002, 243-246; b) Y. Suganuma, S. Tanabe, Y. Sugihara, Y. Kobayashi, Tetrahedron 2018, 74, 115111-59; c) F. Romanov-Michailidis, B. D. Ravetz, D. W. Paley, T. Rovis, J. Am. Chem. Soc. 2018, 140, 5370-5374.

[4] a) K. Masutani, T. Uchida, R. Irie, T. Katsuki, Tetrahedron Lett. 2000, 41, 5119-5123; b) M. R. Patil, A. R. Kapdi, A. V. Kumar, ACS Sustainable Chem. Eng. 2018, 6, 3264-3278.

[5] a) Y. Maeda, N. Kakiuchi, S. Matsumura, T. Nishimura, S. Uemura, Tetrahedron Lett. 2001, 42, 8877-8879; b) Y. Maeda, N. Kakiuchi, S. Matsumura, T. Nishimura, T. Kawamura, S. Uemura, J. Org. Chem. 2002, 67, 6718-6724; c) Y. Maeda, Y. Washitake, T. Nishimura, K. Iwai, T. Yamauchi, S. Uemura, Tetrahedron 2004, 60, 9031-9036; d) A. T. Radosevich, C. Musich, F. D. Toste, J. Am. Chem. Soc. 2005, 127, 1090 1091.

[6] X. Jiang, J. Liu, S. Ma, Org. Process Res. Dev. 2019, 23, 825-835.

[7] S. Sakaguchi, T. Takase, T. Iwahama, Y. Ishii, Chem. Commun. 1998 , 2037-2038.

[8] a) J. Liu, X. Xie, S. Ma, Synthesis 2012, 44, 1569-1576; b) D. Zhai, L. Chen, M. Jia, S. Ma, Adv. Synth. Catal. 2018, 360, 153-160; c) S. A. Miller, K. A. Bisset, N. E. Leadbeater, N. A. Eddy, Eur. J. Org. Chem. 2019, 1413-1417.

[9] a) Y. Dai, F. Ma, Y. Shen, T. Xie, S. Gao, Org. Lett. 2018, 20, 2872-2875; b) M. Satoh, Y. Shibata, K. Tanaka, Chem. Eur. J. 2018, 24, 5434-5438.

[10] Y. Aida, Y. Shibata, K. Tanaka, J. Org. Chem. 2018, 83, 2617-2626.

[11] a) K. Kędziora, A. Díaz-Rodríguez, I. Lavandera, V. Gotor-Fernández, V. Gotor, Green Chem. 2014, 16, 2448-3453; b) L. Martínez-Montero, V. Gotor, V. Gotor-Fernández, I. Lavandera, Green Chem. 2017, 19, 474480.

[12] L. Martínez-Montero, V. Gotor, V. Gotor-Fernández, I. Lavandera, ACS Catal. 2018, 8, 2413-2419

[13] a) P. J. Stang, F. Diederich, Modern Acetylene Chemistry, Wiley-VCH, Weinheim; 1995; b) J. S. Yadav, S. Chandrasekhar in Drug Discovery and Development: Drug Development, Vol. 2 (Eds.: M. S. Chorghade), John Wiley \& Sons, Hoboken, 2007, pp 141-160; c) P. Forgione, L. D. Fader, Sci. Synth. 2008, 36, 531-571; d) H. Qian, D. Huang, Y. Bi, G. Yan, Adv. Synth. Catal. 2019, 361, 3240-3280.

[14] a) C. W. Bradshaw, W. Hummel, C.-H. Wong, J. Org. Chem. 1992, 57, 1532-1536; b) C. Heiss, M. Laivenieks, J. G. Zeikus, R. S. Phillips, Bioorg. Med. Chem. 2001, 9, 1659-1666; c) T. Schubert, W. Hummel, M.-R. Kula, M. Müller, Eur. J. Org. Chem. 2001, 4181-4187; d) T. Schubert, W. Hummel, M. Müller, Angew. Chem. Int. Ed. 2002, 41, 634-637; e) R. van Deursen, W. Stampfer, K. Edegger, K. Faber, W. Kroutil, J. Mol. Catal. 
B: Enzym. 2004, 31, 159-163; f) A. Jakoblinnert, R. Mladenov, A. Paul, F. Sibilla, U. Schwaneberg, M. B. Ansorge-Schumacher, P. Domínguez de María, Chem. Commun. 2011, 47, 12230-12232; g) M. Hamzic, J. Pietruszka, D. Sandkhul, Chirality 2011, 23, E110-E115; h) C. Holec, D. Sandkuhl, D. Rother, W. Kroutil, J. Pietruszka, ChemCatChem 2015, 7, 3125-3130.

[15] a) B. I. Glänzer, K. Faber, H. Griengl, Tetrahedron 1987, 43, 5791-5796; b) C: Waldinger, M. Schneider, M. Botta, F. Corelli, V. Summa, Tetrahedron: Asymmetry 1996, 7, 1485-1488.

[16] a) K. Burgess, L. D. Jennings, J. Am. Chem. Soc. 1991, 113, 6129-6139; b) J. A. Smulik, S. T. Diver, J. Org. Chem. 2000, 65, 1788-1792; c) D. Xu Z. Li, S. Ma, Tetrahedron Lett. 2003, 44, 6343-6346; d) C. Raminelli, J. V. Comasseto, L. H. Andrade, A. L. M. Porto, Tetrahedron: Asymmetry 2004, 15, 3117-3122; e) A. Horváth, J. Benner, J.-E. Bäckvall, Eur. J Org. Chem. 2004, 3240-3243; f) C. Raminelli, N. C. da Silva, A. A. Dos Santos, A. L. M. Porto, L. H. Andrade, J. V. Comasseto, Tetrahedron 2005, 61, 409-415; g) H. Kim, Y. K. Choi, J. Lee, E. Lee, J. Park, M.-J. Kim, Angew. Chem. Int. Ed. 2011, 50, 10944-10948; h) P. Chen, X. Zhu, J. Mol. Catal. B: Enzym. 2013, 97, 184-188; i) J. G. Ferreira, C. R. Princival, D. M. Oliveira, R. X. Nacimiento, J. L. Princival, Org. Biomol. Chem. 2015, 13 6458-6462; j) J. G. Hernández, M. Frings, C. Bolm, ChemCatChem, 2016, 8, 1769-1722; k) D. Koszelewski, F. Borys, A. Brodzka, R. Ostaszewski, Eur. J. Org. Chem. 2019, 1653-1658; I) S. Kawanishi, S. Oki, D. Kundu, S. Akai, Org. Lett. 2019, 21, 2978-2982.

[17] T. Saravanan, A. Chadha, Tetrahedron: Asymmetry 2010, 21, 2973 2980.

[18] a) D. M. Mate, M. Alcalde, Microb. Biotechnol. 2017, 10, 1457-1467; b) C. Romero-Guido, A. Baez, E. Torres, Catalysts 2018, 8, 223.
[19] a) C. C. Gruber, I. Lavandera, K. Faber, W. Kroutil, Adv. Synth. Catal. 2006, 348, 1789-1805; b) A. Díaz-Rodríguez, I. Lavandera, V. Gotor Curr. Green Chem. 2015, 2, 192-211.

[20] R. A. Sheldon, Green Chem. 2017, 19, 18-43.

[21] EATOS: Environmental Assessment Tool for Organic Syntheses, http://www.metzger.chemie.uni-oldenburg.de/eatos/english.htm. See: M. Eissen, J. O. Metzger, Chem. Eur. J. 2002, 8, 3580-3585.

[22] I. Lavandera, A. Kern, B. Ferreira-Silva, A. Glieder, S. de Wildeman, W Kroutil, J. Org. Chem. 2008, 73, 6003-6005.

[23] I. Lavandera, A. Kern, V. Resch, B. Ferreira-Silva, A. Glieder, W. M. F. Fabian, S. de Wildeman, W. Kroutil, Org. Lett. 2008, 10, 2155-2158.

[24] Z. Findrik, D. Vasić-Rački, S. Lütz, T. Daussmann, C. Wandrey, Biotechnol. Lett. 2005, 27, 1087-1095.

[25] W. Stampfer, B. Kosjek, C. Moitzi, W. Kroutil, K. Faber, Angew. Chem. Int. Ed. 2002, 41, 1014-1017.

[26] S. Leuchs, L. Greiner, Chem. Biochem. Eng. Q. 2011, 25, 267-281.

[27] S. Kara, D. Spickermann, A. Weckbecker, C. Leggewie, I. W. C. E. Arends, F. Hollmann, ChemCatChem, 2014, 6, 973-976.

[28] H. Man, K. Kędziora, J. Kulig, A. Frank, I. Lavandera, V. GotorFernández, D. Rother, S. Hart, J. P. Turkenburg, G. Grogan, Top. Catal. 2014, 57, 356-365.

[29] M. Marzorati, B. Danieli, D. Haltrich, S. Riva, Green Chem. 2005, 7, 310315.

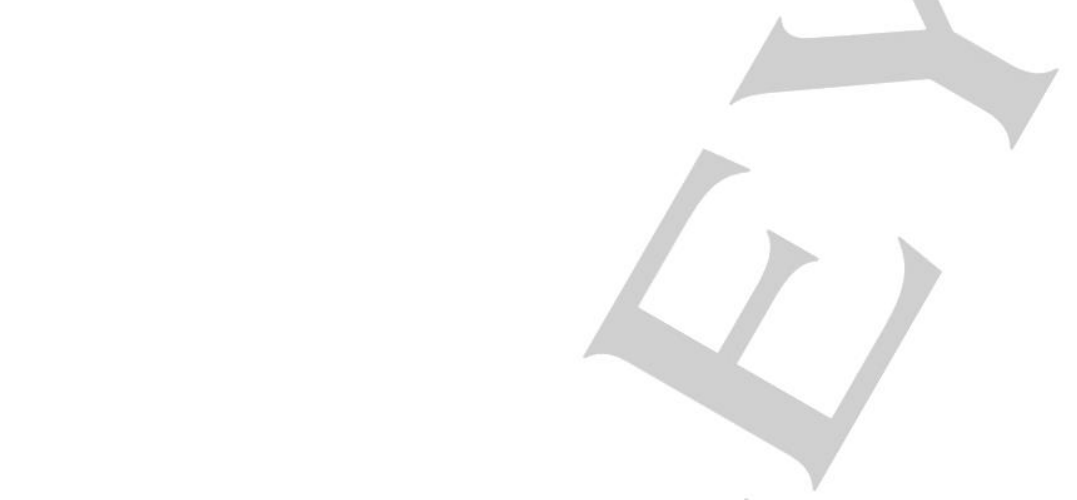




\section{Entry for the Table of Contents}

\section{FULL PAPER}

A mild and general oxidation of propargylic alcohols has been described using the catalytic system composed by the laccase from Trametes versicolor and the oxyradical TEMPO. Stereoselective bioreduction of the corresponding ynones using alcohol dehydrogenases has allowed the development of an efficient deracemization strategy towards the production of $(S)$ and $(R)$ alcohols with excellent selectivity.

Sergio González-Granda, ${ }^{[a]}$ Daniel Méndez-Sánchez, Iván Lavandera* and Vicente Gotor-Fernández*

\section{Page No. - Page No.}

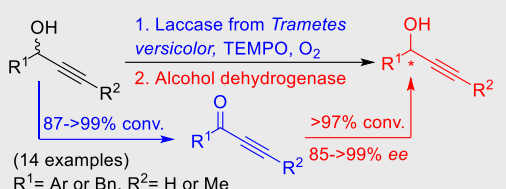

$\mathrm{R}^{1}=\mathrm{Ar}$ or $\mathrm{Bn}, \mathrm{R}^{2}=\mathrm{H}$ or $\mathrm{Me}$
Laccase-mediated oxidations of propargylic alcohols. Application in the deracemization of 1-arylprop-2yn-1-ols in combination with alcohol dehydrogenases 